\title{
Checklist comparison and dominance patterns of the fish fauna at Taim Wetland, South Brazil
}

\author{
Alexandre M. Garcia*, Marlise A. Bemvenuti**, João P. Vieira**, \\ David M. L. Motta Marques*, Marcelo D. M. Burns**, Alex Moresco** \\ and Mario Vinicius L. Condini**
}

Taim Hydrological System is a unique subtropical wetland in southern Brazil harboring an exceptional biological diversity. In 1978, an ecological reserve was established to protect part of this area from increasing anthropogenic impacts in its surroundings. Fishes have been poorly investigated in this system. Based on a multi-gear sampling study encompassing several years (2001-2005), and on comparisons with previous fish inventories, we provide an up-to-date species list of fishes occurring in the Taim Wetland. In addition, we made the first preliminary description of fish dominance patterns found in the main lakes of the system (Flores, Nicola, Jacaré and Mangueira). Checklist comparison resulted in 62 fish species distributed in 24 families, with Characidae (19 species) and Cichlidae (7) showing the highest species richness. Six species are cited for the first time in the reserve: Trachelyopterus lucenai (Auchenipteridae), Hoplosternum littorale (Callichthyidae), Rineloricaria cadeae (Loricariidae), Eigenmannia trilineata (Sternopygidae), Odontesthes mirinensis and O. perugiae (Atherinopsidae). Apparently, the black catfish $T$. lucenai invaded the system in the last decade and became one of the dominant species in the pelagic waters. Although differences in gears hindered direct comparisons, differences in species composition and dominance patterns between shallow margins and pelagic waters of lakes seem to occur in the lakes. A more diverse assemblage dominated by small fishes $(<5 \mathrm{~cm})$ occurred in the protected, vegetated lakes margins. In contrast, an assemblage with lower species richness comprised of larger fishes $(>15 \mathrm{~cm})$ seemed to dominate in pelagic waters.

O Sistema Hidrológico do Taim é um banhando subtropical localizado no sul do Brasil que abriga uma diversidade biológica excepcional. Em 1978, uma reserva ecológica foi estabelecida para proteger parte dessa área do crescente impacto de ações antrópicas nos seus arredores. Os peixes tem sido muito pouco investigados nessa região. Baseado em coletas com vários amostradores durante vários anos (2001-2005), e em comparações com estudos prévios, esse trabalho fornece uma lista de espécies atualizada dos peixes ocorrendo no Taim. Também é apresentada a primeira descrição preliminar dos padrões de dominância nos principais lagos que compõem o sistema (Flores, Nicola, Jacaré e Mangueira). A análise comparada indicou a presença de 62 espécies de peixes distribuídas em 24 famílias, sendo Characidae (19 espécies) e Cichlidae (7) as famílias com o maior número de espécies. Seis espécies são registradas pela primeira vez na reserva: Trachelyopterus lucenai (Auchenipteridae), Hoplosternum littorale (Callichthyidae), Rineloricaria cadeae (Loricariidae), Eigenmannia trilineata (Sternopygidae), Odontesthes mirinensis e O. perugiae (Atherinopsidae). Aparentemente, o penharol T. lucenai invadiu o sistema na última década e tornou-se uma das espécies dominantes nas zonas pelágicas das lagoas. Embora diferenças nos amostradores não permitam comparações diretas, parecem ocorrer diferenças na composição de espécies e padrões de dominância entre as margens rasas e as zonas pelágicas dos lagos. Uma assembléia de peixes mais diversa, dominada por peixes pequenos $(<5 \mathrm{~cm})$ ocorrem nas margens vegetadas e protegidas dos lagos, enquanto uma assembléia menos diversa formada por peixes de maior tamanho $(>15 \mathrm{~cm})$ parece dominar as zonas pelágicas.

Key words: subtropical wetland, Neotropical fishes, Ecological Reserve, Invasive species, Patos-Mirim Lagoon complex.

\footnotetext{
*Universidade Federal do Rio Grande do Sul, Instituto de Pesquisas Hidráulicas, CP 15029, 91501-970 Porto Alegre, RS, Brazil. e-mail: amgarcia@mikrus.com.br (AMB),dmm@iph.ufrgs.br (DMLMM). Send reprint requests to AMG.

**Fundação Universidade Federal de Rio Grande, Depto de Oceanografia, Laboratório de Ictiologia, CP 474, 06201-900 Rio Grande, RS, Brazil. e-mail: docmab@super.furg.br (MAB), vieira@mikrus.com.br (JPV), burnsmdm@hotmail.com (MDMB), alexbio@bol.com.br (AM), condini_oceano@yahoo.com.br (MVLC).
} 


\section{Introduction}

Taim Hydrological System is a unique freshwater wetland ecosystem in southern Brazil encompassing a variety of habitats such as beaches, dunes, forests, grasslands and, especially, lakes and wetlands. Such heterogeneous and productive landscape harbors an exceptional biological diversity, which, in part, motivated Brazilian federal authorities to consider part of this hydrological system as the Taim Ecological Reserve in 1978 (Motta Marques et al., 2002). Such conservation status has been crucial in protecting this area from increasing anthropogenic impacts in its surroundings, such as water diversion for rice irrigation and fishing activities. It is critically important to develop baseline data on aquatic community attributes in this ecological reserve for effective conservation and management in the face of these threats. In 1992, Taim Hydrological System was designated as a research site of the Brazilian Long-Term Ecological Research Program (locally know as PELD, Pesquisas Ecológicas de Longa Duração) to foster continuous ecological research inside the reserve (Seeliger et al., 2002).

Fishes usually represent an important biological component in freshwater wetlands, playing crucial roles in energy flow between lower and higher trophic levels (DeAngelis et al., 2005), in top-down controls via predation (Carpenter, 1985), as important groups sustaining high biological diversity (Bruton
\& Merron, 1990) and as valuable fishery resources for local human populations (Welcomme, 1979). Yet fishes have been poorly investigated inside Taim Reserve. Currently, published information is restricted to taxonomic species lists (Buckup \& Malabarba, 1983, Grosser et al. 1994), description of new species (Buckup, 1981; Reis, 1983) and, more recently, a feeding study (Moresco \& Bemvenuti, 2005). Based on sample collections obtained between 1976 and 1981, Buckup \& Malabarba (1983) provided the first fish inventory, listing 53 species. Other collections between 1985 and 1986, across a larger area revealed 51 species (Grosser et al., 1994). In the last twenty years there has not been field sampling inside the reserve to check the species composition or status of the fish fauna.

Based on a multi-gear sampling study, encompassing several years (2001-2005), we provide an up-to-date species list of fishes occurring in Taim, and a comparison with previous studies. In addition, we also made the first preliminary description of fish dominance patterns found in the main lakes of Taim Hydrological System.

\section{Material and Methods}

Field sampling. Fishes were collected using several sample gears (gillnet, beach seine, dip net and casting net) in the main lakes of the Taim Ecological Reserve: Flores, Nicola, Jacaré and Mangueira (Fig. 1). Three sampling strategies were used:

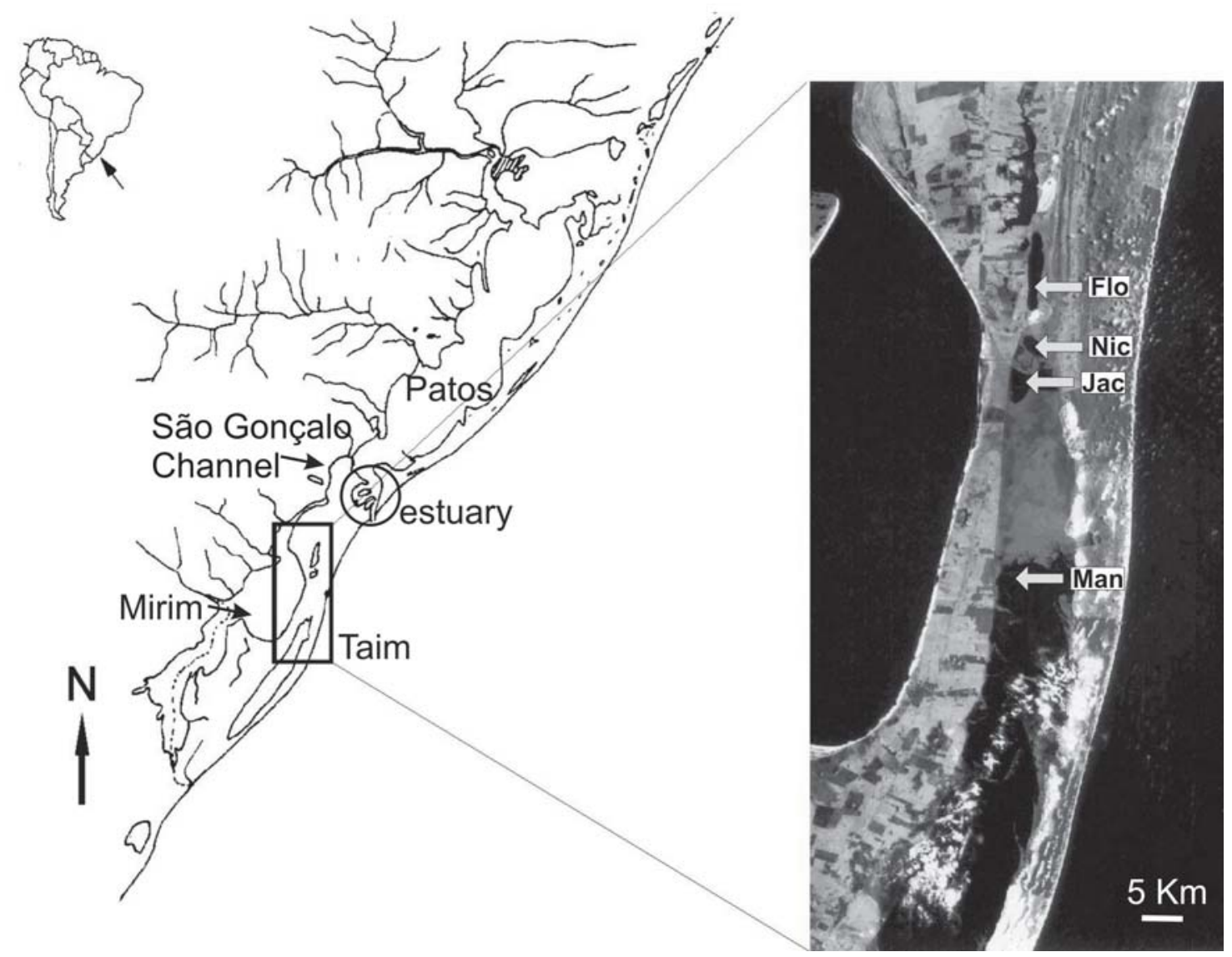

Fig. 1. Patos-Mirim lagoon complex in southern Brazil (left) and Taim Ecological Reserve area (right) with location of sample stations across studied lakes: Flores (Flo), Nicola (Nic), Jacaré (Jac) and Mangueira Norte (Man). 
Table 1. Checklist comparison between fishes captured at the Taim Hydrological system during previous surveys (1.Buckup \& Malabarba, 1983, from 1976 to 1981; 2.Grosser et al., 1994, from 1985 to 1986) and the present study (3. from 2001 to 2005). Common names given in Portuguese.

\begin{tabular}{|c|c|c|c|c|}
\hline $\begin{array}{l}\text { Family } \\
\text { Species }\end{array}$ & $\begin{array}{c}\text { Common } \\
\text { name }\end{array}$ & 1 & 2 & 3 \\
\hline \multicolumn{5}{|l|}{ Clupeidae } \\
\hline Platanichthys platana (Regan, 1917) & Sardinha & $\mathrm{X}$ & $\mathrm{X}$ & $\mathrm{X}$ \\
\hline \multicolumn{5}{|l|}{ Curimatidae } \\
\hline Cyphocharax voga (Hensel, 1870) & Biru & $\mathrm{X}$ & $\mathrm{X}$ & $\mathrm{X}$ \\
\hline \multicolumn{5}{|l|}{ Erythrinidae } \\
\hline Hoplias malabaricus (Bloch, 1794) & Traíra & $\mathrm{X}$ & $\mathrm{X}$ & $\mathrm{X}$ \\
\hline \multicolumn{5}{|l|}{ Characidae } \\
\hline Astyanax eigenmanniorum (Cope, 1894) & Lambari & $\mathrm{X}$ & $\mathrm{X}$ & $\mathrm{X}$ \\
\hline A. fasciatus (Cuvier, 1819) & Lambari & $\mathrm{X}$ & $\mathrm{X}$ & $\mathrm{X}$ \\
\hline A. jacuhiensis (Cope, 1894) & Lambari & $\mathrm{X}$ & $\mathrm{X}$ & $\mathrm{X}$ \\
\hline Astyanax sp. & Lambari & & & $\mathrm{X}$ \\
\hline Bryconamericus iheringii (Boulenger, 1887) & Lambari & $\mathrm{X}$ & $\mathrm{X}$ & $\mathrm{X}$ \\
\hline Charax stenopterus (Cope, 1894) & Lambari & $\mathrm{X}$ & $\mathrm{X}$ & $\mathrm{X}$ \\
\hline Cheirodon ibicuhiensis Eigenmann, 1915 & Lambari & $\mathrm{X}$ & $\mathrm{X}$ & $\mathrm{X}$ \\
\hline C. interruptus (Jenyns, 1842) & Lambari & $\mathrm{X}$ & $\mathrm{X}$ & $\mathrm{X}$ \\
\hline Cyanocharax alburnus (Hensel, 1870) & Lambari & $\mathrm{X}$ & $\mathrm{X}$ & $\mathrm{X}$ \\
\hline Hyphessobrycon anisitsi (Eigenmann, 1907) & Lambari & & $\mathrm{X}$ & $\mathrm{X}$ \\
\hline H. bifasciatus Ellis, 1911 & Lambari & $\mathrm{X}$ & $\mathrm{X}$ & $\mathrm{X}$ \\
\hline H. boulengeri (Eigenmann, 1907) & Lambari & $\mathrm{X}$ & $\mathrm{X}$ & $\mathrm{X}$ \\
\hline H. luetkenii (Boulenger, 1887) & Lambari & $\mathrm{X}$ & $\mathrm{X}$ & $\mathrm{X}$ \\
\hline H. meridionalis Ringuelet, Miquelarena \& Menni, 1978 & Lambari & $\mathrm{X}$ & $\mathrm{X}$ & $\mathrm{X}$ \\
\hline Macropsobrycon uruguayanae Eigenmann, 1915 & Lambari & $\mathrm{X}$ & $\mathrm{X}$ & $\mathrm{X}$ \\
\hline Mimagoniates inequalis (Eigenmann, 1911) & Lambari & $\mathrm{X}$ & $\mathrm{X}$ & \\
\hline Oligosarcus jenynsii (Günther, 1864) & Dentuço & $\mathrm{X}$ & $\mathrm{X}$ & $\mathrm{X}$ \\
\hline O. robustus Menezes, 1969 & Dentuço & $\mathrm{X}$ & $\mathrm{X}$ & $\mathrm{X}$ \\
\hline Pseudocorynopoma doriae Perugia, 1891 & Lambari & $\mathrm{X}$ & $\mathrm{X}$ & $\mathrm{X}$ \\
\hline \multicolumn{5}{|l|}{ Crenuchidae } \\
\hline Characidium rachovii Regan, 1913 & & $\mathrm{X}$ & $\mathrm{X}$ & $\mathrm{X}$ \\
\hline \multicolumn{5}{|l|}{ Auchenipteridae } \\
\hline Trachelyopterus lucenai Bertoletti, Silva \& Pereira, 1995 & Penharol & & & $\mathrm{X}$ \\
\hline \multicolumn{5}{|l|}{ Aspredinidae } \\
\hline Bunocephalus iheringii Boulenger, 1891 & & $\mathrm{X}$ & $\mathrm{X}$ & $\mathrm{X}$ \\
\hline \multicolumn{5}{|l|}{ Heptapteridae } \\
\hline Heptapterus sympterygium Buckup, 1988 & & $\mathrm{X}$ & $\mathrm{X}$ & $\mathrm{X}$ \\
\hline Pimelodella australis Eigenmann, 1917 & Mandi & $\mathrm{X}$ & $\mathrm{X}$ & $\mathrm{X}$ \\
\hline Rhamdia quelen (Quoy \& Gaimard, 1824) & Jundiá & $\mathrm{X}$ & $\mathrm{X}$ & $\mathrm{X}$ \\
\hline \multicolumn{5}{|l|}{ Pimelodidae } \\
\hline Parapimelodus nigribarbis (Boulenger, 1889) & Mandi & $\mathrm{X}$ & $\mathrm{X}$ & $\mathrm{X}$ \\
\hline Pimelodus maculatus Lacepède, 1803 & Pintado & $\mathrm{X}$ & $\mathrm{X}$ & $\mathrm{X}$ \\
\hline \multicolumn{5}{|l|}{ Pseudopimelodidae } \\
\hline Microglanis cottoides (Boulenger, 1891) & & $\mathrm{X}$ & $\mathrm{X}$ & $\mathrm{X}$ \\
\hline \multicolumn{5}{|l|}{ Trichomycteridae } \\
\hline Homodiaetus anisitsi Eigenmann \& Ward, 1907 & & $\mathrm{X}$ & $\mathrm{X}$ & $\mathrm{X}$ \\
\hline
\end{tabular}

a) During 14 field surveys in 2001 (July, December), 2002 (April, July, November), 2003 (February, July, October, December), and 2004 (March, May, July, September, December) gillnet sampling was conducted in the deeper $(>1.5 \mathrm{~m})$, pelagic waters of each lake. Each gillnet set was comprised of four panels $(8 \times 2 \mathrm{~m})$, each panel with adjacent meshes sizes of $15,20,30$ and $35 \mathrm{~mm}$. These four panels were put together side by side to form a gillnet set before each sampling. Their mesh sequence (increasing or decreasing from left to right) were previously chosen by a random procedure each time the gillnet set was prepared for sampling. This allow for different gillnet set combinations, regarding panel order, depending if individual panels started from an increasing mesh order from left to right (15 to 35), or in a decreasing order (35 to 15 ). For each field survey and each lake, two gillnet sets were underwater during a period of time ranging from 17 to $24 \mathrm{~h}$, which was similar among lakes $($ Flores $=17-19 \mathrm{~h}$, Nicola $=17-18$, Jacaré $=$

\begin{tabular}{|c|c|c|c|c|}
\hline $\begin{array}{l}\text { Family } \\
\text { Species } \\
\end{array}$ & $\begin{array}{c}\text { Common } \\
\text { name }\end{array}$ & 1 & 2 & 3 \\
\hline \multicolumn{5}{|l|}{ Callichthyidae } \\
\hline Corydoras paleatus (Jenyns, 1842) & & $\mathrm{X}$ & $\mathrm{X}$ & $\mathrm{X}$ \\
\hline Callichthys callichthys (Linnaeus, 1758) & & $\mathrm{X}$ & $\mathrm{X}$ & $\mathrm{X}$ \\
\hline Hoplosternum littorale (Hancock, 1828) & Tamboatá & & & $\mathrm{X}$ \\
\hline \multicolumn{5}{|l|}{ Loricariidae } \\
\hline Hisonotus taimensis (Buckup, 1981) & Limpa-fundo & $\mathrm{X}$ & $\mathrm{X}$ & $\mathrm{X}$ \\
\hline Hypostomus commersoni Valenciennes, 1836 & Cascudo & $\mathrm{X}$ & $\mathrm{X}$ & $\mathrm{X}$ \\
\hline Loricariichthys anus (Valenciennes, 1836) & Cascudo-viola & $\mathrm{X}$ & $\mathrm{X}$ & $\mathrm{X}$ \\
\hline Rineloricaria cadeae (Hensel, 1868) & Cascudo-viola & & & $\mathrm{X}$ \\
\hline R. longicauda Reis, 1983 & Cascudo-viola & $\mathrm{X}$ & $\mathrm{X}$ & $\mathrm{X}$ \\
\hline \multicolumn{5}{|l|}{ Sternopygidae } \\
\hline Eigenmannia trilineata López \& Castello, 1966 & & & & $\mathrm{X}$ \\
\hline \multicolumn{5}{|l|}{ Hypopomidae } \\
\hline Brachyhуроротиs spp & & $\mathrm{X}$ & & \\
\hline \multicolumn{5}{|l|}{ Gymnotidae } \\
\hline Gymnotus carapo Linnaeus, 1758 & Tuvira & & $\mathrm{X}$ & \\
\hline \multicolumn{5}{|l|}{ Rivulidae } \\
\hline Cynopoecilus melanotaenia (Regan, 1912) & & $\mathrm{X}$ & & \\
\hline \multicolumn{5}{|l|}{ Anablepidae } \\
\hline Jenynsia multidentata (Jenyns, 1842) & Barrigudinho & $\mathrm{X}$ & $\mathrm{X}$ & $\mathrm{X}$ \\
\hline \multicolumn{5}{|l|}{ Poeciliidae } \\
\hline Cnesterodon decemmaculatus (Jenyns, 1842) & Barrigudinho & $\mathrm{X}$ & $\mathrm{X}$ & $\mathrm{X}$ \\
\hline Phalloceros caudimaculatus (Hensel, 1868) & Barrigudinho & $\mathrm{X}$ & $\mathrm{X}$ & $\mathrm{X}$ \\
\hline \multicolumn{5}{|l|}{ Atherinopsidae } \\
\hline Odontesthes bonariensis (Valenciennes, 1835) & Peixe-rei & $?$ & $\mathrm{X}$ & $\mathrm{X}$ \\
\hline O. humensis de Buen, 1953 & Peixe-rei & $?$ & $X$ & $\mathrm{X}$ \\
\hline O. mirinensis Bemvenuti, 1995 & Peixe-rei & $?$ & & $\mathrm{X}$ \\
\hline O. perugiae Evermann \& Kendall, 1906 & Peixe-rei & ? & & $\mathrm{X}$ \\
\hline O. retropinnis (de Buen, 1953) & Peixe-rei & $?$ & $X$ & $\mathrm{X}$ \\
\hline \multicolumn{5}{|l|}{ Synbranchidae } \\
\hline Synbranchus marmoratus Bloch, 1795 & & $\mathrm{X}$ & $\mathrm{X}$ & $\mathrm{X}$ \\
\hline \multicolumn{5}{|l|}{ Cichlidae } \\
\hline Australoheros facetum (Jenyns, 1842) & Cará & $\mathrm{X}$ & $\mathrm{X}$ & $\mathrm{X}$ \\
\hline Cichlasoma portalegrense (Hensel, 1870) & Cará & $\mathrm{X}$ & & $\mathrm{X}$ \\
\hline Crenicichla lepidota Heckel, 1840 & Joaninha & $\mathrm{X}$ & $\mathrm{X}$ & $\mathrm{X}$ \\
\hline C. punctata Hensel, 1870 & Joaninha & $\mathrm{X}$ & $\mathrm{X}$ & $\mathrm{X}$ \\
\hline Gymnogeophagus gymnogenys (Hensel, 1870) & Cará & $\mathrm{X}$ & $\mathrm{X}$ & $\mathrm{X}$ \\
\hline G. rhabdotus (Hensel, 1870) & Cará & $\mathrm{X}$ & $\mathrm{X}$ & $\mathrm{X}$ \\
\hline Geophagus brasiliensis (Quoy \& Gaimard, 1824) & Cará & $\mathrm{X}$ & $\mathrm{X}$ & $\mathrm{X}$ \\
\hline \multicolumn{5}{|l|}{ Mugilidae } \\
\hline Mugil platanus Gunther, 1880 & Tainha & & $\mathrm{X}$ & \\
\hline \multicolumn{5}{|l|}{ Gobiidae } \\
\hline Ctenogobius shufeldti (Jordan \& Eigenmann, 1887) & & $\mathrm{X}$ & & $\mathrm{X}$ \\
\hline
\end{tabular}

17-18), with exception of Mangueira Norte (22-24) due to logistic reasons.

b) Between March 2004 to February 2005 five beach seine (9m long, $2.4 \mathrm{~m}$ high, mesh size $13 \mathrm{~mm}$ wings and $5 \mathrm{~mm}$ center and bag) hauls were made monthly in the margins of each lake, always in shallow waters $(<1.5 \mathrm{~m})$.

c) Dip nets and casting nets were used in habitats where gillnets and beach seines could not operate properly (e.g. dense vegetated habitats, deep and narrow channels). These samples were used only as complementary data in the species richness inventory (Table 1), and were not considered in the dominance pattern analysis (Table 2).

All captured fishes were preserved in 10\% formalin and later identified, counted and measured to the nearest $\mathrm{mm}$. Individuals of each species were deposited in the Ichthyologic Collection of the Universidade Federal de Rio Grande (FURG). 
Data analyses. We used combinations of frequency of occurrence and caught per unit of effort (CPUE) expressed in percentage $(\% \mathrm{FO}$ and $\%$ CPUE) to assess dominance patterns of the fish assemblage. $\% \mathrm{FO}$ was calculated as the ratio of the number of occurrences of a species divided by the total number of hauls (beach seine data) or number of field surveys (gillnet data) (x 100). \%CPUE was calculated as the species CPUE divided by the total species CPUE (x 100). For beach seine samples, CPUE for each species in each lake was calculated as the total number of individuals captured divided by the total number of hauls. For gillnet samples, CPUE for each species in each lake was calculated as the total number of individuals captured divided by the total number of hours the net remained underwater.

Species showing $\% \mathrm{FO} \geq$ average $\% \mathrm{FO}$ in each site collection were considered frequent fishes, whereas those with $\% \mathrm{FO}$ $<$ average $\%$ FO were considered rare fishes (Garcia et al., 2004). A similar method was applied to \%CPUE, resulting in High Abundance (\%CPUE $\geq$ average \%CPUE) and Low Abundance $(\%$ CPUE $<$ average \%CPUE) categories. Finally, combinations of $\% \mathrm{FO}$ and $\% \mathrm{CPUE}$ were used to classify four fish groups in terms of relative importance: 1 . High abundance and Frequent ( $\geq \% \mathrm{CPUE}, \geq \% \mathrm{FO}), 2$. High Abundance and Rare ( $\geq \% \mathrm{CPUE}$, $<\% \mathrm{FO}), 3$. Low abundance and Frequent ( $<\%$ CPUE, $\geq \%$ FO) and 4 . Low abundance and Rare $(<\%$ CPUE, $<\% \mathrm{FO})$.

\section{Results}

Checklist comparison resulted in 62 fish species occurring at Taim Wetland distributed in 24 families, with Characidae (19 species) and Cichlidae (7) showing the highest species richness (Table 1). A total of 57 species comprising 20 families were captured from 2001 to 2005 , which represents a slightly greater number than previous studies conducted from 1976 to 1981 (53 species) and from 1985 to 1986 (51 species). Six species were recorded for the first time in the study area: Trachelyopterus lucenai (Auchenipteridae), Hoplosternum littorale (Callichthyidae), Rineloricaria cadeae (Loricariidae), Eigenmannia trilineata (Sternopygidae), Odontesthes mirinensis and $O$. perugiae (Atherinopsidae). In contrast, five species previously described for the region were not caught in the present study: Mimagoniates inequalis (Characidae), Brachyhypopomus spp. (Hypopomidae), Gymnotus carapo (Gymnotidae), Cynopoecilus melanotaenia (Rivulidae) and Mugil platanus (Mugilidae) (Table 1).

Species richness strongly varied across fish gears. Beach seine samples yielded highest richness (49), followed by casting net (34), gillnet (32) and dip net (29). A few species were captured exclusively by only one gear: eight by beach seine samples (Ctenogobius shufeldti, Eigenmannia trilineata, Gymnogeophagus rhabdotus, Homodiaetus anisitsi, Hyphessobrycon anisitsi, H. boulengeri, Microglanis cottoides, Rineloricaria cadeae), five by gillnet (Australoheros facetum, Hoplosternum littorale, Odontesthes bonariensis, Parapimelodus nigribarbis and Trachelyopterus lucenai), and only one for dip net (Hyphessobrycon meridionalis) and casting net (Heptapterus sympterygium).
Dominance patterns based on beach seine and gillnet data, revealed that 16 species (out of 53 caught only with these two gears) were dominant (\%CPUE $\geq$ average $\%$ CPUE) and frequent $(\% \mathrm{FO} \geq$ average $\% \mathrm{FO}$ ) across all lakes (Table 2). Dominant fishes according to beach seine samples were the characids Cyanocharax alburnus, Bryconamericus iheringii, Cheirodon interruptus, Hyphessobrycon luetkenii, the one-sided livebearer Jenynsia multidentata, the sardine Platanichthys platana, the silverside O. mirinensis and the peppered corydoras Corydoras paleatus, which together made up $82.2 \%$ of the total abundance. In the gillnet samples, nine dominant fishes accounted for $87.5 \%$ of the total abundance: the curimatid Cyphocharax voga, the characids Astyanax fasciatus, Oligosarcus robustus, O. jenynsii, the silversides Odontesthes mirinensis, $O$. perugiae, the trahira Hoplias malabaricus, the freshwater catfishes Pimelodus maculatus and Trachelyopterus lucenai.

There were clear differences in the average size of dominant fishes caught by beach seine and gillnet sampling (Table 3). Average TL of dominant fishes in beach seine samples ranged from 34.0 to $44.0 \mathrm{~mm}$, whereas the average TL of dominant gillnet fishes varied from 123.3 to $299.7 \mathrm{~mm}$. The only species occurring as dominant in both gears, the silverside $O$. mirinensis, also showed lower average size in beach seine samples (68.1) when compared to gillnet (193.6). A similar trend was observed for the dominant gillnet species that also occurred in beach seine samples; lower average size in beach seine and higher average in gillnet. The only two exceptions seemed to be the thraira $H$. malabaricus and the catfish P. maculatus, which were captured in similar average size by both gears.

\section{Discussion}

Sampling strategy comparison. In order to avoid misleading comparisons it seems appropriate to highlight important sampling strategy differences between the current and previous studies (Buckup \& Malabarba, 1983, Grosser et al., 1994). Our standardized beach seine and gillnet samples was concentrated mainly in the major lakes Flores, Nicola, Jacaré and Mangueira. Otherwise, dip net and casting net were used only to browse for new species that could be evading gillnet and beach seine and, therefore, were employed sparsely in time and space, without sampling effort standardization.

In contrast, the main goal in Buckup \& Malabarba (1983) and Grosser et al. (1994) was to provide a first account of the fish species inhabiting Taim, with no attempted to describe fish assemblage structure or dynamics. Therefore, their sampling strategy was to survey without temporal replication as many habitats as possible using several available fish gears such as gill and trammel nets, casting nets, dip nets, including fishing with different hooks and line. Sampling effort in Buckup \& Malabarba (1983) was concentrated mainly in artificial channels, in small natural channels and at the northwestern portion of Mangueira lake. No samples were obtained inside the wetland or swamp proper, probably due to difficulties in sampling in this highly vegetated habitat. In contrast, Grosser et al. (1994) surveyed a much broader area encom- 
Table 2. Relative importance based on frequency of occurrence (\%FO) and percent abundance (\%CPUE) of the fishes captured from 2001 to 2005 in Taim's lakes (Flores, Nicola, Jacaré and Mangueira Norte) by beach seine (shallow margins) and gillnet (pelagic waters) sampling. 1. High abundance and Frequent, 2. High Abundance and Rare, 3. Low abundance and Frequent and 4. Low abundance and Rare. See Materials and Methods for further details of categories (1-4).

\begin{tabular}{|c|c|c|c|c|c|c|c|c|c|}
\hline \multirow[t]{2}{*}{ Species } & \multicolumn{4}{|c|}{ Beach Seine } & \multicolumn{4}{|c|}{ Gillnet } & \multirow[t]{2}{*}{$\mathrm{N}$} \\
\hline & Flo & $\mathrm{Nic}$ & Jac & Man & Flo & Nic & Jac & Man & \\
\hline Cyanocharax alburnus & 1 & 1 & 1 & 1 & & & 4 & & 5139 \\
\hline Jenynsia multidentata & 1 & 1 & 1 & 1 & & & & & 1168 \\
\hline Bryconamericus iheringii & 1 & 1 & 1 & 4 & & & & 4 & 1795 \\
\hline Hyphessobrycon luetkenii & 3 & 1 & 1 & 3 & & & & & 1039 \\
\hline Platanichthys platana & 1 & 3 & 3 & 1 & & & 4 & & 3979 \\
\hline Cheirodon interruptus & 1 & 3 & 1 & 4 & & & & & 1828 \\
\hline Corydoras paleatus & 4 & 1 & 4 & & & & & & 2167 \\
\hline Odontesthes mirinensis & 3 & 4 & 4 & 1 & 4 & 3 & 3 & 1 & 2461 \\
\hline Oligosarcus jenynsii & 3 & 3 & 2 & 4 & 1 & 2 & 1 & 2 & 2417 \\
\hline Cyphocharax voga & 4 & 4 & 3 & 4 & 1 & 1 & 1 & 1 & 929 \\
\hline Astyanax fasciatus & 3 & 4 & 4 & 4 & 1 & 1 & 2 & 1 & 947 \\
\hline Oligosarcus robustus & 4 & 4 & 4 & & 1 & 1 & 1 & 3 & 521 \\
\hline Trachelyopterus lucenai & & & & & 2 & 1 & 1 & 3 & 439 \\
\hline Hoplias malabaricus & 4 & 3 & 4 & 4 & 1 & 3 & 3 & 4 & 184 \\
\hline Odontesthes perugiae & 4 & & 4 & 4 & 4 & 4 & 3 & 1 & 226 \\
\hline Pimelodus maculatus & & 4 & & & 4 & 3 & 1 & 4 & 171 \\
\hline Astyanax eigenmanniorum & 3 & 4 & 3 & 3 & 4 & 4 & 3 & 3 & 578 \\
\hline Astyanax jacuhiensis & 4 & 4 & 3 & 3 & 4 & 4 & 4 & 3 & 231 \\
\hline Loricariichthys anus & 4 & 3 & 4 & & 3 & 4 & 3 & 4 & 175 \\
\hline Odontesthes humensis & 4 & 4 & 4 & 4 & & 4 & 3 & 3 & 246 \\
\hline Cheirodon ibicuhiensis & 3 & 3 & 4 & 4 & & & & & 1008 \\
\hline Homodiaetus anisitsi & 4 & 3 & 3 & & & & & & 178 \\
\hline Astyanax spp & 4 & 4 & 4 & 4 & 4 & 4 & 4 & 3 & 193 \\
\hline Charax stenopterus & & 3 & 4 & 4 & & & & & 117 \\
\hline Pseudocorynopoma doriae & 4 & 4 & 4 & & & & & & 112 \\
\hline Pimelodella australis & 4 & 4 & 4 & & & & & 4 & 67 \\
\hline Geophagus brasiliensis & 4 & 3 & 4 & 4 & 4 & 4 & 4 & & 64 \\
\hline Odontesthes bonariensis & & & & & & 4 & 4 & 3 & 53 \\
\hline Odontesthes retropinnis & & & & 4 & & & & 4 & 46 \\
\hline Rineloricaria longicauda & 4 & 4 & & 4 & 4 & & & 4 & 45 \\
\hline Gymnogeophagus gymnogenys & 4 & 3 & 4 & & & & 4 & & 42 \\
\hline Microglanis cottoides & 4 & 4 & 4 & 4 & & & & & 38 \\
\hline Macropsobrycon uruguayanae & 4 & 4 & 4 & & & & & & 37 \\
\hline Hisonotus taimensis & 4 & 4 & 4 & & & & & & 24 \\
\hline Hypostomus commersoni & & 4 & 4 & 4 & & & & 4 & 16 \\
\hline Hoplosternum littorale & & & & & 4 & 4 & 4 & & 14 \\
\hline Parapimelodus nigribarbis & & & & & 4 & & & 4 & 13 \\
\hline Rhamdia sapo & & & & 4 & & 4 & 4 & 4 & 11 \\
\hline Crenicichla punctata & & 4 & 4 & & & & & 4 & 9 \\
\hline Crenicichla lepidota & & 4 & 4 & & 4 & & 4 & 4 & 8 \\
\hline Bunocephalus iheringii & & 4 & & & & & & & 7 \\
\hline Australoheros facetum & & & & & & & & 4 & 7 \\
\hline Hyphessobrycon bifasciatus & 4 & 4 & 4 & & & & & & 3 \\
\hline Hyphessobrycon boulengeri & & & 4 & & & & & & 3 \\
\hline Characidium rachovii & & 4 & 4 & & & & & & 2 \\
\hline Cnesterodon decemmaculatus & 4 & & 4 & & & & & & 2 \\
\hline Ctenogobius shufeldti & & & 4 & & & & & & 2 \\
\hline Phalloceros caudimaculatus & & & 4 & & & & & & 2 \\
\hline Cichlasoma portalegrense & & & & & & & & 4 & 1 \\
\hline Eigenmannia trilineata & & & 4 & & & & & & 1 \\
\hline Gymnogeophagus rhabdotus & & & & 4 & & & & & 1 \\
\hline Hyphessobrycon anisitsi & & & & 4 & & & & & 1 \\
\hline Rineloricaria cadeae & & 4 & & & & & & & 1 \\
\hline Total number of species & 31 & 37 & 39 & 26 & 19 & 19 & 23 & 27 & \\
\hline
\end{tabular}

passing 52 sampling stations across several habitats such as small natural channels, major lakes (Flores, Nicola, Jacaré and Mangueira), smaller ephemeral lakes, artificial drainage channels and areas inside the swamp. Although Grosser and col- leagues (1994) surveyed a larger area, their sampling was restricted to early spring (September and November of 1985 and 1986) and late summer (March 1986), with no sampling during winter and autumn. 
Table 3. Mean, standard deviation (SD), minimum (Min), maximum (Max) and number of cases (N) of total lenght (TL, mm) of the dominant fishes captured by beach seine (shallow margins) and gillnet (pelagic waters) sampling in Taim's lakes (Flores, Nicola, Jacaré and Mangueira Norte). Dominant species in each gear (according Table 1) are shown in gray.

\begin{tabular}{|c|c|c|c|c|c|c|c|c|c|c|}
\hline \multirow[t]{2}{*}{ Species } & \multicolumn{5}{|c|}{ Beach Seine } & \multicolumn{5}{|c|}{ Gillnet } \\
\hline & Mean & SD & Min & Max & $\mathrm{N}$ & Mean & SD & Min & Max & $\mathrm{N}$ \\
\hline Cyanocharax alburnus & 37.0 & 9.3 & 10 & 71 & 3197 & 74.0 & & & & 1 \\
\hline Jenynsia multidentata & 34.0 & 9.9 & 16 & 97 & 1088 & & & & & \\
\hline Bryconamericus iheringii & 41.1 & 11.4 & 19 & 81 & 1103 & 98.8 & 6.1 & 85 & 105 & 13 \\
\hline Hyphessobrycon luetkenii & 44.0 & 10.6 & 21 & 76 & 765 & & & & & \\
\hline Platanichthys platana & 34.2 & 8.3 & 20 & 72 & 1657 & 56.0 & & & & 1 \\
\hline Cheirodon interruptus & 37.6 & 5.3 & 21 & 60 & 583 & & & & & \\
\hline Corydoras paleatus & 42.2 & 10.5 & 25 & 72 & 458 & & & & & \\
\hline Odontesthes mirinensis & 68.1 & 24.3 & 16 & 208 & 1400 & 193.6 & 23.9 & 92 & 283 & 566 \\
\hline Oligosarcus jenynsii & 63.8 & 32.1 & 30 & 205 & 235 & 153.2 & 23.2 & 12 & 270 & 2024 \\
\hline Cyphocharax voga & 95.8 & 53.1 & 28 & 215 & 61 & 185.8 & 40.3 & 25 & 416 & 867 \\
\hline Astyanax fasciatus & 77.1 & 23.2 & 12 & 119 & 86 & 123.3 & 17.6 & 86 & 181 & 860 \\
\hline Oligosarcus robustus & 75.5 & 33.0 & 35 & 158 & 19 & 238.4 & 61.6 & 103 & 432 & 485 \\
\hline Trachelyopterus lucenai & & & & & & 198.5 & 20.6 & 21 & 295 & 455 \\
\hline Hoplias malabaricus & 286.9 & 69.3 & 23 & 485 & 54 & 299.7 & 54.6 & 142 & 550 & 131 \\
\hline Odontesthes perugiae & 88.9 & 40.5 & 51 & 245 & 27 & 197.4 & 30.6 & 47 & 279 & 198 \\
\hline Pimelodus maculatus & 222.5 & 67.2 & 175 & 270 & 2 & 288.2 & 36.4 & 143 & 373 & 167 \\
\hline
\end{tabular}

Species list comparison. In contrast with previous surveys (Buckup \& Malabarba 1983, Grosser et al. 1994), our current findings recorded six new fish species to the Taim Ecological Reserve, including two new Families (Auchenipteridae and Sternopygidae). Three were small $(<30 \mathrm{~cm}$ ) freshwater catfishes (Trachelyopterus lucenai, Hoplosternum littorale, and Rineloricaria cadeae) belonging to three different families (Auchenipteridae, Callichthyidae, and Loricariidae, respectively). These catfishes have no commercial importance in the fishery activities around the reserve. Two other species were silversides (Odontesthes mirinensis and O. perugiae, Atherinopsidae), which represent important components of the fishery landings in Mirim Lagoon and surrounding areas. The sixth species was the small $(<25 \mathrm{~cm})$ electric fish Eigenmannia trilineata (Sternopygidae). Although it has no commercial value in fisheries, some species of this family are common in the aquarium trade. Currently, there is scarce information available regarding the ecology and natural history of most sternopygid species (Froese \& Pauly, 2005).

Among these new records it is worth noting the occurrence of the black catfish $T$. lucenai. This species was absent in the previous surveys (Buckup \& Malabarba, 1983; Grosser et al., 1994) and now appears as a dominant species (i.e., abundant and frequent) in deeper, pelagic waters of the reserve's major lakes, especially in Nicola and Jacaré. Its occurrence in the Patos Lagoon drainage seems to be fairly recent. In 1995, Bertoletti and collaborators described T. lucenai as a new species for the Patos Lagoon and Uruguay River drainages. According to these authors, preferential habitats of the black catfish seemed to be near the margins of lowland tributaries with slow water current and muddy bottom. They also noted that since 1989, when it was first mentioned by Bertolletti et al. (1992), the species has shown an accelerated increase in numbers in the tributaries of the Patos Lagoon system, especially around Guaíba Lake located north of Patos Lagoon. Becker (1998) described an omnivorous diet with a tendency towards piscivory for the black catfish population inhabiting Guaíba Lake. Similarly, Moresco \& Bemvenuti (2005) also found an omnivorous diet composed mainly of insects and fish, followed by mollusks and crustaceans for the black catfish population of Taim. They also observed a highly opportunistic feeding behavior, which was illustrated by the occurrence of the blind-snake Amphisbaena darwinii in the stomach contents of one individual.

We captured the first specimens of the black catfish in Taim during a pilot field survey in March 2001. Following the initial survey, individuals have been captured in apparently increasing abundance in the majority (12 out of 16) of the gillnet surveys conducted from July 2001 to December 2004. Surprisingly, it was not captured in the monthly beach seine hauls $(\mathrm{n}=20)$ conducted from March 2004 to February 2005. These findings, therefore, seemed to suggest that pelagic waters rather than shallow margins of lakes constitute the preferential habitat for the species in Taim. However, we also have to take into account that, in contrast with gillnets, beach seine samples were obtained only during the diurnal period. Hence, we should not reject the alternative hypothesis that $T$. lucenai could display daily movements between pelagic waters and shallow margins in lakes.

Apparently, high abundance and diversity of food items associated with suitable habitat features found in the lowvelocity lake waters of Taim represented favorable conditions for the invasion and proliferation of the black catfish. Other intrinsic biological features also could help explain the apparent spreading of the species to Taim from its original area (Bertolletti et al., 1995) located in the northern portion of the Patos Lagoon and Uruguay drainages. First, occurrence of strong spines, with well developed bony hooks on its anterior face, in the pectoral and dorsal fins could prevent predation. Second, the anal fin of adult males is usually modified into an intromittent organ aiding insemination. As pointed out by Burns et al. (2002) such reproductive modes could enhance probability of fertilization and allow temporal and 
spatial segregation of mating and spawning, which could be helpful in its dispersal across habitats. Third, although there is no specific information available for T. lucenai, Burns et al. (2002) also reported that in some species of this family (Auchenipteridae), females isolated from males can continue to lay fertilized eggs suggesting they are able to store sperm.

Five fish species previously cited occurring in Taim were not captured in the present work. With exception of the marine-estuarine mullet M. platanus (see discussion below), they are usually small $(<5 \mathrm{~cm})$ freshwater fishes captured apparently in very low number in the previous surveys: Mimagoniates inequalis (Characidae), Brachyhypopomus spp (Hypopomidae), Gymnotus carapo (Gymnotidae), Cynopoecilus melanotaenia (Rivulidae). The characid was recorded in both studies, whereas Brachyhypopomus and $C$. melanotaenia were caught only by Buckup \& Malabarba (1983), and G. carapo only by Grosser et al. (1994).

Gymnotus carapo feeds mainly at night using its electric organ to locate its prey (Albert \& Crampton, 2003). Otherwise, $C$. melanotaenia is a small $(<4 \mathrm{~cm})$ annual fish that has eggs adapted to survive within the substrate during dry episodes until the return of the rainy conditions (Arenzon et al., 2002). Such biological features and behaviors, associated with our relatively poor sampling effort in other habitats aside from lakes, could explain why these species were absent in our survey. Further sampling targeting specifically these species or representative habitats would be necessary to evaluate if they are locally extinct within the reserve boundaries.

Dominance patterns. Beach seine hauls in lakes shallow marginal areas and gillnet sampling in pelagic waters resulted in contrasting fish assemblage species composition and dominance patterns. A more diverse (in terms of species richness) assemblage dominated by small fishes $(<5 \mathrm{~cm})$ such as characids, a livebearering fish, a freshwater sardine, silverside juveniles and a corydora characterized the shallow, more protected and vegetated lakes margins. In contrast, an assemblage with lower species richness and comprised by larger fishes $(>15 \mathrm{~cm})$ such as a curimatid, larger characids and silversides, trahira and freshwater catfishes seemed to dominated in pelagic waters.

Such contrasting patterns of small fishes inhabiting shallow, protected areas $v s$. large fishes found in deeper, pelagic waters are also common in other aquatic habitats like estuaries (e.g. Patos Lagoon estuary, Vieira et al., 1998) and freshwater wetlands (e.g., Everglades, Chick et al., 2004). For instance, in the freshwater wetlands of southern Florida (USA), small poeciliids and cyprinodontids represent the major energy resource for higher trophic level consumers, whereas large predators such as largemouth bass Micropterus salmoides and Florida gar Lepisosteus platyrhrincus seemed to be much less abundant numerically (Chick et al., 2004).

However, the differences in species composition and dominance patterns between shallow margins and deeper pelagicwaters described in this study should not be considered a definitive figure due to important differences between gears. Beach seines are an active fishing gear usually employed to sample small littoral fish, whereas gillnets are a passive fishing method designed to capture large, faster swimming, midwater fish (Hayes, 1989; Rozas \& Minello, 1997). Additionally, differences between mesh sizes of both gears (lowest seine's mesh was $5 \mathrm{~mm}$, whereas gillnet was $15 \mathrm{~mm}$ ) also hinder direct comparison. Hence, the observed differences in the fish fauna could be partially result from gear capture efficiency (sensu Rozas \& Minello, 1997) or mesh selectivity. Future field sampling studies with a controlled experimental design would be necessary to accurately distinguish between-site and between-gear differences.

Estuarine species occurrence. Some of the fishes that have been reported to occur in Taim have a wide distribution along the Patos-Mirim Lagoon complex, including a few species, which use the estuarine zone of Patos Lagoon during their whole lifecycle (e.g., the one-sided livebearer Jenynsia multidentata and the American freshwater goby Ctenogobius shufeldti) or parts of their life-cycle such as juvenile forms of marine spawners (e.g., the mullet Mugil platanus). Due to their biological features, only the one-sided livebearer and the American freshwater goby could have established isolated populations in Taim.

The one-sided livebearer has a broad tolerance to physicochemical variation, particularly of salinity (Garcia et al., 2004), and ranges from Argentina to Rio de Janeiro, Brazil (Ghedotti \& Weitzman, 1996). It is a small viviparous fish $(<10$ $\mathrm{cm})$, achieving maturity in short time intervals $(2-5 \mathrm{mo})$ (Wischnath, 1993) and showing preference for vegetated, shallow water habitats (Garcia \& Vieira, 1997). Therefore, the densely vegetated, shallow water lakes of Taim (Motta Marques et al., 2002) seem to provide an optimal habitat for the development of a J. multidentata population. Probably due to its usually low density, much less information is available regarding habitat requirements of the American freshwater goby inhabiting the Patos-Mirim Lagoon complex.

In contrast with Grosser et al. (1994), who captured three sub-adult females (ca. $33 \mathrm{~cm}$ ) in November 1985 and January 1986, we did not collect mullets in any of our samples, even with gillnets and casting nets, which are considered efficient gears to capture fast-swimming adult mullets (Hayes 1989). Buckup \& Malabarba (1983) also did not catch mullets in their survey in 1979, although they cited oral communications (likely from fishers) describing the occurrence of mullets in Taim.

Mullets are marine spawners that utilize estuarine areas such as the Patos Lagoon estuary as nursery habitats for their juveniles (Vieira \& Scalabrin, 1991). Considering the large distance between its marine spawning and estuarine nursery grounds and Taim freshwater wetland (see Fig. 1) the absence of mullets in Taim is not surprising. It is also important to take into account the construction of a dam in 1977 at the São Gonçalo Channel, which connects Patos and Mirim Lagoons (see Fig. 1). Burns et al. (2006) suggests the dam acts as a barrier hindering the entrance of estuarine water into Mirim Lagoon, and subsequently, did not allow the dispersion of marine and estuarine fishes in great numbers from Patos Lagoon to Mirim Lagoon.

In summary, our current checklist comparison enlarges the previously known number of fishes occurring in Taim from 53 to 
62 species distributed among 24 families. Six species are cited for the first time in the reserve, including an apparently invasive species, the black catfish. In a relatively small lapse of time, since the last fish inventory in 1985-1986, the black catfish became one of the dominant species in the pelagic waters. Five species previously recorded inside the reserve were not collected in the present study. Low densities, special biological features and low sampling effort in some habitats could explain the absence of these species. Although differences in gears used to sample different habitats did not allow direct comparisons and conclusions, differences in species composition and dominance patterns between shallow margins and pelagic deeper waters of lakes seem to occur in Taim Hydrological System.

\section{Acknowledgements}

Thanks to the numerous colleagues and technicians that assist in the field and laboratory work, especially Antonio R. T. Bueno (IPH-UFRGS) and Nilton A. Abreu (DOC-FURG); to Luiz Malabarba for helping with taxonomic identification; to David Hoeinghaus for English revision. AMG acknowledges fellowship support provided by CNPq (Grant 150868/2003-0). PELD-Sítio 7 (Sistema Hidrológico do Taim) provided logistical and financial support (Grant 52.0027/98-1).

\section{Literature Cited}

Albert, J. S. \& G. R. William. 2003. Seven new species of the Neotropical electric fish Gymnotus (Teleostei, Gymnotiformes) with a redescription of G. carapo (Linnaeus). Zootaxa, 287: 1-54.

Arenzon, A., C. A. Lemos \& M. B. C. Bohrer. 2002. The influence of temperature on the embryonic development of the annual fish Cynopoecilus melanotaenia (Cyprinodontiformes, Rivulidae). Brazilian Journal of Biology, 62(4B): 743-747.

Becker, F. G. 1998. Feeding habits of Trachelyopterus lucenai (Pisces, Auchenipteridae) in lake Guaíba, RS, Brazil. Biociências, 6: 89-98.

Bertolletti, J. J., E. H. L. Pereira \& J. F. P. Silva. 1992. Nota sobre o gênero Trachelyopterus Valenciennes, 1840, no estado do Rio Grande do Sul, Brasil (Siluriformes, Auchenipteridae). Comunicações do Museu de Ciências da PUCRS, Série Zoologia, 169-177.

Bruton, M. N. \& G. S. Merron. 1990. The proportion of different ecoethological sections of reproductive guilds of fishes in some African inland waters. Environmental Biology of Fishes, 28: 179-187.

Buckup, P. A. 1981. Microlepidogaster taimensis sp. n., novo Hypoptopomatinae da Estação Ecológica do Taim, Rio Grande do Sul, Brasil (Ostariophysi, Loricariidae). Iheringia, Série Zoologia, 60:19-31.

Buckup, P. A. \& L. R. Malabarba. 1983. A list of the fishes of the Taim Ecological Station, RS, Brazil. Iheringia, Série Zoologia, 63:103-113.

Burns, J. R., A. D. Meisner, S. H. Weitzman \& L. R. Malabarba. 2002. Sperm and spermatozeugma ultrastructure in the inseminating catfish, Trachelyopterus lucenai (Ostariophysi: Siluriformes: Auchenipteridae). Copeia, 2002: 173-179.

Burns, M. D. M., A. M. Garcia, J. P. Vieira, M. A. Bemvenuti, D. M. L. Motta Marques \& M. V. Condini. 2006. Evidence of habitat fragmentation affecting fish movement between the Patos and Mirim coastal lagoons in southern Brazil. Neotropical Ichthyology, 4(1):69-72.

Carpenter, S. R., J. F. Kitchell \& J. R. Hodgson. 1985. Cascading trophic interactions and lake productivity. BioScience, 25: 634-639.
Chick, J. H., C. R. Ruetz III \& J. C. Trexler. 2004. Spatial scale and abundance patterns of large fish communities in freshwater marshes of the Florida Everglades. Wetlands, 24(3): 652-664.

Deangelis, D. L., J. C. Trexler \& W. F. Loftus. 2005. Life history trade-offs and community dynamics of small fishes in a seasonally pulsed wetland. Canadian Journal of Fisheries and Aquatic Science, 62: 781-790.

Froese, R. \& D. Pauly. (Eds). 2005. FishBase. World Wide Web electronic publication. www.fishbase.org, version (05/2005).

Garcia, A. M. \& J. P. Vieira. 1997. Abundância e diversidade da assembléia de peixes dentro e fora de uma pradaria de Ruppia maritima L., no estuário da Lagoa dos Patos (RS-Brasil). Atlântica, 19: 161-181.

Garcia, A. M., J. P. Vieira, K. O. Winemiller \& M. B. Raseira. 2004. Reproductive cycle and spatiotemporal variation in abundance of the one-sided livebearer Jenynsia multidentata, in Patos Lagoon, Brazil. Hydrobiologia, 515: 39-48.

Garcia, A. M., J. P. Viera, K. O. Winemiller \& A. M. Grimm. 2004. Comparison of the 1982-1983 and 1997-1998 El Niño effects on the shallow-water fish assemblage of the Patos Lagoon estuary (Brazil). Estuaries, 27: 905-914.

Ghedotti, M. J. \& S. H. Weitzman. 1996. A new species of Jenynsia (Cyprinodontiformes: Anablepidae) from Brazil with comments on the composition and taxonomy of the genus. Natural History Museum, The University of Kansas, Lawrence, 1-25.

Grosser, K. M., W. R. Koch \& S. Drugg-Hahn. 1994. Ocorrência e distribuição de peixes na estação ecológica do Taim, Rio Grande do Sul, Brasil, (Pisces, Teleostomi). Theringia, Série Zoologia, 77: 89-98.

Hayes, J. W. 1989. Comparison between a fine mesh trap net and five other fishing gears for sampling shallow-lake fish communities in New Zealand. New Zealand Journal of Marine and Freshwater Research, 23: 321-324.

Moresco, A. \& M. A. Bemvenuti. 2005. Morphologic features and feeding analysis of the black catfish Trachelyopterus lucenai Bertoletti, Pezzi da Silva \& Pereira (Siluriformes, Auchenipteridae). Acta Limnologica Brasiliensia, 17(1):37-44.

Motta Marques, D. M. L., C. Tucci, D. Calazans, V. L. M. Callegaro \& A. Villanueva. 2002. O Sistema Hidrológico do Taim - site 7. Pp. 125-144. In: U. Seeliger, C.V. Cordazzo \& F. Barbosa (Eds.) Os sites e o programa Brasileiro de pesquisas ecológicas de longa duração. Belo Horizonte, MCT-CNPq, 184p.

Reis, R. E. 1983. Rineloricaria longicauda e Rineloricaria quadrensis, duas novas espécies de Loricariinae do sul do Brasil (Pisces, Siluriformes, Loricariidae). Iheringia, Série Zoologia, 62:61-80.

Rozas, L. P. \& T. J. Minello. 1997. Estimating densities of small fishes and decapod crustaceans in shalow estuarine habitats: a review of sampling design with focus on gear selection. Estuaries, 20: 199-213.

Seeliger, U., C. V. Cordazzo \& F. Barbosa. 2002. Os sites e o programa Brasileiro de pesquisas ecológicas de longa duração. Belo Horizonte, MCT-CNPq, 184p.

Vieira, J. P. \& C. Scalabrin. 1991. Migração reprodutiva da "tainha" (Mugil platanus Gunther, 1980) no sul do Brasil. Atlântica Rio Grande, 13: 131-141.

Vieira, J. P., J. P. Castello \& L. E. Pereira. 1998. Ictiofauna. Pp. 6068. In: U. Seeliger, C. Odebrecht \& J. P. Castello (Eds.) Os ecossistemas costeiro e marinho do extremo sul do brasil. Editora Ecoscientia Ltda, Rio Grande, 326p.

Welcomme, R. L. 1979. Fisheries ecology of floodplain rivers. Longman, London, 317p.

Wischnath, L. 1993. Atlas of livebearers of the world. T.F.H. Publications, Neptune City, New Jersey, 336p.

Received September 2005 Accepted May 2006 